\title{
The Skill of Solving Problems of Educational Counselors
}

\author{
Noora Ali Mohammed, Prof. Dr . Mohammed Kazem Aljizani \\ College of Basic Education - Al-Mustansiriya University
}

DOI: $10.37648 / \mathrm{ijrssh.v10i04.045}$

Received:10 th August, 2020; Accepted:18 ${ }^{\text {th }}$ September, 2020; Published: 26th December, 2020

\begin{abstract}
The current research aims to identify the The skill of solving problems of educational counselors, as the research consisted of (400) guides and guides. The researcher built a The skill of solving problems scale based on Heppner theory ) The researcher used the statistical methods: T-test for one sample (T_test), T-test for two independent samples, Pearson correlation coefficient, and the current search results showed that educational counselors have The skill solving problems at a high level in light of the difference between the calculated mean and the hypothetical mean, and in the light of the findings of the researcher presented a number of recommendations and suggestion.
\end{abstract}

\section{RESEARCH PROBLEM}

Psychologists and researchers in the field of psychological counseling emphasized the necessity of training educational counselors to acquire the skill of problem-solving as the basis of the guiding process that makes the counselor effective in the profession of psychological counseling, as the role of the educational counselor in the school has become no less important and influential than any element of the educational process. It is an important factor in the guiding process whose success or failure depends on his personal competence, his characteristic of stability, flexibility, and good awareness, his good experience in the field of social relations, and his knowledge of personal, educational and professional facts (Mohsen, 1993, p: 6)

Patterson (1962) emphasized that the success of the extension process depends on trained people who accomplish their work with great skill, have extensive experience and the ability to establish human relationships inside and outside the educational institution (Taher, 2006, p. 3)
The skill, as a type of learning, may require cognitive aspects and mental processes, as the first level of skill learning is the perception that is included in the mental processes, and accordingly the skill is not only an explicit activity, but it has another aspect, which is the cognitive aspect and the skill is the ability to employ knowledge in an effective way to achieve the goals And the ability to achieve knowledge in different situations. (Mustafa, 2011)

\section{RESEARCH IMPORTANCE}

The problem-solving skill is one of the basic skills that a psychological counselor must master and learn, and here questions may arise about the need for an efficient psychological counselor! What are his performance that he requires at this stage of this era, his tasks, his sufficiency and levels of preparation, and how do the vision combine in answering these questions that haunted the researcher's mind since thinking about this research by revealing the correlation between the problem-solving skill of the psychological counselor and his training in mastering it since the years of education The first and through its preparation stages, which reflects on his 
indicative performance and leads him to creativity and innovation in his field of work with the new mentors in this new era. (Al-Bahdal, 2014: 222)

It is noted that problem-solving skill is one of the main concerns in psychological counseling because it is a type of performance and is subject to the same influences that affect other types of behavior. Therefore, we find that there are variables such as motivation and previous experience that affect the level of performance to solve the problem (Al-Khalidi and Abbas, 2015: 173)

\section{First: The theoretical importance}

The research is concerned with achieving the theoretical aspect of shedding light on the problem-solving skill of educational counselors and the possibility of using it scientifically in the extension process.It is concerned with the group targeted by the current research, namely the educational counselors, being the leaders relied upon in building a healthy society to ensure that the right person is placed in the right place.

\section{Second: Application importance}

The current research prepared a measure for measuring the research variable (problem-solving skill of educational counselors)

Utilizing the results of the current research to develop the guiding process and diagnose the basic aspect of the educational guide's work, which is the skill in solving problems.

\section{search limits}

The current research is determined by educational counselors (males, females) working in elementary, intermediate and preparatory schools affiliated to the General Directorates of Education (Rusafa 1, Rusafa 2, Rusafa 3, Al-Karkh 1, Al-Karkh 2, and Al-Karkh 3). In the city of Baghdad for the academic year (2019/2020) morning government schools.

\section{Defining terms}

Define Nazih (1998)

The problem-solving skill of the psychological counselor is a cognitive mental activity organized to solve a specific difficulty, in which the psychological counselor uses previous experiences with the elements of the current situation to reach a solution and deduce various alternative solutions that can be generalized to similar situations through a total awareness of the components of the problem (Nazih, 1998)

Hebnir (1984)

"A set of operations that the individual performs using the information that he has already learned and the skills he has acquired in overcoming a situation in a new and unfamiliar way for him in controlling it, and reaching a solution to it." (Hepnier, 1984, p .: 82)

\section{Theoretical definition}

The researcher adopted Hebner's definition (1984) because she adopted Hepnier's theory in the skill of solving problems

Procedural definition

The total score that the respondent obtains by answering the paragraphs of the scale prepared for this research

Third: the educational guide

Definition of the Ministry of Education 2002

The educational advisor is one of the faculty members who are scientifically and educationally qualified to practice his guidance and directional work in the school and study the educational, social, behavioral and psychological problems of students, and to help them find appropriate solutions and treatments for these problems, discover people with scientific capabilities and abilities, their interests and orientations, and work on developing them through the use of all available data sources After ensuring the accuracy and validity of these data (Ministry of Education, 2002, p. 30)

\section{THE SECOND CHAPTER:}

\section{THE THEORETICAL FRAMEWORK AND PREVIOUS STUDIES}

The second half of the twentieth century witnessed a tremendous scientific and technological development that resulted in many new concepts such as the explosion of knowledge, the information age, and the communications revolution. All this made the educational institution a small community in which relationships are intertwined, intertwined and intertwined, which may increase the chances of problems that must be reflected in their impact on work on the one hand and on individuals on the other hand, but information increases at a tremendous speed, so the traditional methods used in preparing Mentors have not yet yielded the required learning due to their inability 
to meet the requirements of the mentoring process and the needs of mentors. (Al-Bahdal, 2014: 123)

The results of recent studies indicate that psychological counseling is the activity carried out by the psychological counselor who is proficient in the art of employing his skill in solving problems and employing his scientific knowledge and personal experience in the feasibility of professional academic bodies that practice his work. Professional work by overcoming obstacles that hinder their personal growth when facing these obstacles, as well as helping them achieve the optimal growth of their personal resources (Abu Gedo, 2008)

\section{The concept of problem-solving skill}

A skill means mastery, competence and experience in an activity, and the main element in any skill is the ability of an individual to apply a range of experiences effectively (Hamdy and Khattabiah, 2013, p .: 220)

Problem solving is thinking directed towards a specific problem by performing two types of mental activity, namely arriving at specific responses and formulating them, and then choosing the appropriate response from among them to solve this problem. The counselor faces an infinite number of problems in the educational institution that he must formulate a specific outline of their responses. . And choose the appropriate response to solve various problems. It is affected by many factors that lead to solving various problems as a skill between individuals, as negative correlations have been found between brain activity during problem solving under cognitive stress and intelligence, which means that individuals who are mentally qualified during problem solving are less mentally active compared to those with moderate mental abilities And then the efficiency theory appears to confirm this, as intelligence is not a function of how difficult the work the brain performs, but rather it is related to the efficiency of performing this work, and the individual controls the solution of the problem through the behaviors that come with it, which should include the behavior of trial and error, insight and analysis (Al-Qatami and AlZaidoon, 2000, 2009)As for problem-solving skill, it is a mental activity that contains many interrelated mental processes such as images, memory, imagination, abstraction, analysis, synthesis, intuitive speed and insight, in addition to employing information, skills, abilities and various processes when an individual faces a problem in an attempt to overcome the difficulties that prevent access to this situation (Dareb, 2014, $\mathrm{p} . .339$ )

And if we want to limit the skill that must be available in the psychological counselor

1-Sensory skill

If the average person limits his perceptual skill to what is tangible, then the skills of the mentor should not be limited to what is tangible, so he should be aware of what the student says to himself in an inaudible way or what is hidden behind his weakness. He smiled due to the problems he was going through(harris,k. \& hal pin ,G.,1985,136-140)

Cognitive skills can be identified as follows

1-Body integrity and feeling together

2-Particularly perceived transparency

3-Awareness of inner impulses which is called inspiration

4-Accuracy of observation

5-The ability to perceive visuals accurately in their timing and is related to reaction behavior

\section{2-Defining the problem}

it is the guide's ability to define the problem accurately and formulate it in clear words

Hypotheses: It is the guide's ability to produce the largest number of alternatives and solutions to the problem facing him

Choosing the most appropriate alternative: It is the ability of the guide to choose the appropriate alternative to start implementing it in order to solve the problem

Verification of the hypotheses: It is the ability of the guide to conduct an interim evaluation of the solution that he started implementing (Hepnier, 1984)

\section{Previous studies}

1-Study (Muhaidat and Sha'ban, 1997 AD)

This study aims to know the methods and strategies that educational counselors use in dealing with crises resulting from fire injuries to reduce the negative effects resulting from the crisis. The study concluded that educational counselors tend to use methods and strategies that require high skills, namely psychological, behavioral, family and collective therapy in addition to using Individual interviews and the skill of confrontation, and the study also found the need to train mentors on how to conduct 
informative interviews, including basic skills, in order to succeed in his work. (Muhaidat and Shaaban, 1997, p.94) 2-Study Al-Adl and Abdel-Wahhab (2003)

This study aimed to identify differences between male and female counselors in the ability to solve problems, and the result was in favor of males, and this result contradicts the results of other studies such as one (Al-Adl and AbdelWahab, 2003).

\section{3-John's study (2010)}

This study aimed to identify the actual role of the psychological counselor. The sample of the study included (95) counselors from the US state of Connecticut. The results of the study revealed that the most practiced role by the psychological counselor is the ability to solve problems, followed by providing psychological and educational counseling to students, parents and teachers and carrying out activities. Respiratory referral, conducting various assessments and measurements, contacting parents, then conducting individual and group counseling sessions to solve the psychological, social and educational problems facing students. (John, B. 2010, p: 224)

\section{CHAPTER III}

\section{FIRST: RESEARCH METHODOLOGY}

To achieve the goals of the current research, a specific scientific method must be followed, if the researcher relies on the relational (descriptive) approach, as it is considered a fundamental pillar of scientific research and is considered by researchers to study many human fields (Mahlem, 2000: 333).

\section{Population of the Research}

The current research community consisted of educational counselors and of both genders present in elementary, intermediate, preparatory, and secondary schools affiliated to the General Directorates of Education in Baghdad Governorate (Rusafa I, Rusafa II, Rusafa III, Karkh I, Karkh II and Karkh III) morning study for the academic year (2019-2020), totaling (1840) male and female guides, distributed by gender, with (629) male and female mentors (1211) male and female mentors, Table (1) illustrates this.

Table (1)

The research community is distributed according to the General Directorates of Education and gender

\begin{tabular}{|c|c|c|c|c|}
\hline \multirow{3}{*}{ Numbering } & \multirow{3}{*}{$\begin{array}{l}\text { General Directorate of } \\
\text { Education, } \quad \text { Baghdad } \\
\text { Governorate }\end{array}$} & \multicolumn{2}{|l|}{ gender } & \multirow{3}{*}{ Total } \\
\hline & & & & \\
\hline & & Males & Females & \\
\hline 1 & Al-Rusafa 1 & 96 & 255 & 351 \\
\hline 2 & Al-Rusafa 2 & 108 & 222 & 330 \\
\hline 3 & Al-Rusafa 3 & 93 & 101 & 194 \\
\hline 4 & Al-Karkh 1 & 91 & 188 & 279 \\
\hline 5 & Al-Karkh 2 & 91 & 244 & 335 \\
\hline 6 & Al-Karkh 3 & 150 & 201 & 351 \\
\hline \multicolumn{2}{|l|}{ Total } & 629 & 1211 & 1840 \\
\hline
\end{tabular}




\section{Third: Research Sample}

The research sample is a partial group of the research community, and it is better representative of the community's elements, as the results of that sample can be generalized to the entire community and make inferences about the features of the statistical community (Abbas, Muhammad and others, 2009: 219)

\section{Statistical analysis sample}

For the purpose of conducting statistical analysis for the scale of problem-solving and positive thinking, the analysis sample was chosen by the random cluster method and amounted to (400) male and female instructors by (200) male and (200) female guides distributed over the General Directorates of Education (Rusafa 1, Rusafa 2, Rusafa 3, Karkh 1, Al-Karkh 2, Al-Karkh 3) in Baghdad Governorate and Table (2) illustrates this

Table (2)

Distribution of research sample individuals (statistical analysis) according to the name of the directorate and gender.

\begin{tabular}{|l|l|l|l|l|}
\hline \multirow{2}{*}{ Numbering } & $\begin{array}{l}\text { General Directorate of } \\
\text { Education, } \\
\text { Governorate }\end{array}$ & \multicolumn{2}{|l|}{ gender } & \multirow{2}{*}{ Total } \\
\cline { 3 - 5 } & & & \\
& & & \\
& & & \\
\hline 1 & Males & Females & \\
\hline 2 & Al-Rusafa 1 & 35 & 30 & 65 \\
\hline 3 & Al-Rusafa 2 & 42 & 33 & 75 \\
\hline 4 & Al-Rusafa 3 & 58 & 45 & 103 \\
\hline 5 & Al-Karkh 1 & 25 & 30 & 50 \\
\hline 6 & Al-Karkh 2 & 15 & 25 & 40 \\
\hline Total & Al-Karkh 3 & 30 & 37 & 67 \\
\hline
\end{tabular}

\section{2-Application sample}

The most important steps in conducting most psychological research is choosing the individuals of the research sample that must be properly representative of the community (Lefrancois, 2000: 12). ) A guide and (100) female guides from the original community for research from elementary, middle, secondary and preparatory schools covered by educational guidance in the six public directorates in Baghdad governorate, and the application was carried out on (12/22/2019) and continued until $(2 / 15 / 2020)$, as shown in Table (3) 
Table (3)

Distribution of the application sample personnel according to the directorate name and gender

\begin{tabular}{|c|c|c|c|c|}
\hline \multirow{3}{*}{ Numbering } & \multirow{3}{*}{$\begin{array}{l}\text { General Directorate of } \\
\text { Education, } \\
\text { Governorate }\end{array}$} & \multicolumn{2}{|c|}{ gender } & \multirow{3}{*}{ Total } \\
\hline & & \multirow{2}{*}{ Males } & \multirow[b]{2}{*}{ Females } & \\
\hline & & & & \\
\hline 1 & Al-Rusafa 1 & 14 & 12 & 26 \\
\hline 2 & Al-Rusafa 2 & 16 & 16 & 32 \\
\hline 3 & Al-Rusafa 3 & 22 & 20 & 42 \\
\hline 4 & Al-Karkh 1 & 19 & 20 & 39 \\
\hline 5 & Al-Karkh 2 & 15 & 17 & 32 \\
\hline 6 & Al-Karkh 3 & 14 & 15 & 29 \\
\hline \multicolumn{2}{|l|}{ Total } & 100 & 100 & 200 \\
\hline
\end{tabular}

\section{Fourth: Research Tools}

In order to achieve the objectives of the research, the researcher built the problem-solving skill scale, the positive thinking scale, and the following is a review of the procedures:

\section{Defining the concept}

Specialists in psychometrics refer to the need to define the theoretical and scientific foundations upon which they relied in building the scale

\section{Problem-solving skill scale}

The researcher adopted the definition of problem-solving skill from the processes that the individual performs according to Heppner's theory, using the information he had previously learned and the skills he acquired in overcoming a situation in a new and unfamiliar way for him in controlling it, and arriving at a solution to it (Heppner, 1984)

\section{Determine the fields of scale}

The areas of the concept of problem-solving skill have been identified in light of the definition and theory adopted as follows

1-Feeling the problem: the guide's ability to deal with the problems of daily life in a positive way

2-Defining the problem: it is the guide's ability to define the problem accurately and formulate it in clear words.
3-Hypotheses: It is the guide's ability to produce the largest number of alternatives and solutions to the problem facing him

4-Choosing the most appropriate alternative: It is the ability of the guide to choose the appropriate alternative to start implementing it in order to solve the problem 5-Verification of the hypotheses: It is the ability of the guide to conduct an interim evaluation of the solution that he started implementing (Hepnier, 1984)

\section{The validity of the scale paragraphs}

In order to achieve this, the researcher presented the two scales (problem-solving skills) of (40) paragraph (2), in their preliminary form, to a group of arbitrators specialized in the field of education and psychology, and their number reached (17) arbitrators in an appendix (4), in order to issue their judgments on The extent of its validity, soundness of wording and suitability for the purpose for which it was developed, as well as the suitability of the paragraphs to the fields, as well as the validity of the alternatives used to answer; To analyze the experts' opinions on the scale paragraphs, the researcher used the chi-square test $(\mathrm{Ca} 2)$ for one sample, and the paragraph is accepted when the calculated chi-square value is greater than the tabular value of (3.84) at the level of significance (0.05) as in Table (4) 
Table (4)

The arbitrators' opinion is a measure of validity of problem-solving skills

\begin{tabular}{|c|c|c|c|c|c|c|}
\hline \multirow[t]{2}{*}{ Domains } & \multirow{2}{*}{$\begin{array}{l}\text { Paragraph } \\
\text { numbers }\end{array}$} & \multirow{2}{*}{$\begin{array}{l}\text { Number of } \\
\text { acceptors }\end{array}$} & \multirow{2}{*}{$\begin{array}{l}\text { Number of } \\
\text { opponents }\end{array}$} & \multicolumn{2}{|c|}{ Square value as any } & \multirow{2}{*}{$\begin{array}{l}\text { Indication } \\
\text { level } \\
(0,05)\end{array}$} \\
\hline & & & & Calculated & Tabular & \\
\hline \multirow{2}{*}{$\begin{array}{l}\text { Feeling of } \\
\text { trouble }\end{array}$} & 8 ، 8 ، 1، 2، 2، & 17 & Zero & 17 & \multirow{10}{*}{3,84} & Function \\
\hline & $6 \cdot 5$ & 15 & 2 & 9.94 & & Function \\
\hline \multirow{2}{*}{$\begin{array}{l}\text { Defining the } \\
\text { problem }\end{array}$} & 7 ، 6، 5، 2، 2، & 17 & 0 & 17 & & Function \\
\hline & $8 ، 4$ & 11 & 6 & 1.47 & & $\begin{array}{ll}\text { Not } & \text { a } \\
\text { function }\end{array}$ \\
\hline \multirow[t]{2}{*}{ Assumptions } & 8 ، 7، 5، 4، 3، & 17 & 0 & 17 & & Function \\
\hline & $6 \cdot 2$ & 10 & 7 & 0.52 & & $\begin{array}{ll}\text { Not } & \text { a } \\
\text { function }\end{array}$ \\
\hline \multirow{2}{*}{$\begin{array}{l}\text { Choose the } \\
\text { most } \\
\text { appropriate } \\
\text { alternative }\end{array}$} & 8 ( 1، 4، 5، 5، & 17 & 0 & 17 & & Function \\
\hline & 3 ، & 14 & 3 & 7.11 & & Function \\
\hline \multirow{2}{*}{$\begin{array}{l}\text { Checking } \\
\text { Assumptions }\end{array}$} & 7 ، 3 & 17 & 0 & 17 & & Function \\
\hline & 8 (6، 6، 5، 1 & 15 & 2 & 9.94 & & Function \\
\hline
\end{tabular}

When viewing Table (6) and after performing this procedure, it was found that all the scale paragraphs are statistically significant at a level of significance (0.05) except for paragraphs (4 and 8) of the second component and paragraphs (2 and 6) of the third component are not a function that has been deleted so that the scale becomes After validating the scale, it consists of (36) paragraphs

\section{Scale correction}

It means the respondents' answer to all the scale paragraphs and extract the total score by collecting the response scores on the scale and verifying this. The following weights have been determined for the alternatives $(5,4,3,2,1)$. If the respondent puts a sign on the alternatives (very large), he gives (5), and if he puts a sign on the alternative (large) then he gives a score (4), and if he puts a sign on the alternative (Average) is given a score of (3), and if a sign is given to the alternative (a few) then it is given a score (2), and if a sign is given to the alternative (very little) then the score is (1)

\section{Preparing scale instructions}

The scale instructions are considered the guide that guides the respondent, so it was taken into account in preparing the scale instructions that they be clear, simple and understandable, and a sign () is placed under the choice that applies to the respondent, and the researcher confirmed the confidentiality of the answer, and not asking the respondent to mention the name and use the answer for the purposes of scientific research Just

\section{Statistical analysis of scale paragraphs}

The analysis of the scale paragraphs statistically is one of the basic requirements for building psychological and educational standards, as the analysis may not reveal the validity or validity of the measures more accurately, so we use statistical analysis of the paragraphs (Ebel, 1972: 406) 
The discriminatory strength of the paragraphs of the scale of problem-solving skill

For the purpose of extracting the discriminatory power of the paragraphs, the (40) paragraphs of the scale were applied to a randomly selected sample of the research community amounting to (400) mentors, and after correcting their answers, the grades were arranged from the highest total score to the lowest overall score, then the two extreme groups were determined at (27\%) From the sample members from each group, then the sample members in each group from the upper and lower groups (108) became a guide and a guide as in Table (5)

Table (5)

The discriminatory power of the two-group problem-solving skill scale items

\begin{tabular}{|c|c|c|c|c|c|c|}
\hline \multirow[t]{2}{*}{$\mathrm{N}$} & \multicolumn{2}{|c|}{ Top group } & \multicolumn{2}{|c|}{ Lower group } & \multirow{2}{*}{$\begin{array}{l}\text { T-test value } \\
\text { Calculated }\end{array}$} & \multirow[t]{2}{*}{ indication } \\
\hline & SMA & $\begin{array}{l}\text { standard } \\
\text { deviation }\end{array}$ & SMA & $\begin{array}{l}\text { standard } \\
\text { deviation }\end{array}$ & & \\
\hline 1 & 4.00 & 0.937 & 3.28 & 1.023 & 5.339 & Function \\
\hline 2 & 4.05 & 0.873 & 3.37 & 0.954 & 5.429 & Function \\
\hline 3 & 4.16 & 0.779 & 3.32 & 0.894 & 7.379 & Function \\
\hline 4 & 4.01 & 0.748 & 3.13 & 1.071 & 6.992 & Function \\
\hline 5 & 3.88 & 0.801 & 3.06 & 1.034 & 6.545 & Function \\
\hline 6 & 3.94 & 0.862 & 3.28 & 1.014 & 5.130 & Function \\
\hline 7 & 3.88 & 0.889 & 3.37 & 0.912 & 4.227 & Function \\
\hline 8 & 3.85 & 0.862 & 3.44 & 1.007 & 3.192 & Function \\
\hline 9 & 3.86 & 0.847 & 3.32 & 0.955 & 4.369 & Function \\
\hline 10 & 4.12 & 0.854 & 3.26 & 1.009 & 6.798 & Function \\
\hline 11 & 4.05 & 0.894 & 3.38 & 1.039 & 5.051 & Function \\
\hline 12 & 3.91 & 0.948 & 3.43 & 0.909 & 3.807 & Function \\
\hline 13 & 4.05 & 0.783 & 3.27 & 0.945 & 6.583 & Function \\
\hline 14 & 3.96 & 0.796 & 3.20 & 1.056 & 5.963 & Function \\
\hline 15 & 3.91 & 0.798 & 3.13 & 0.869 & 6.846 & Function \\
\hline 16 & 3.97 & 0.971 & 3.29 & 0.988 & 5.070 & Function \\
\hline 17 & 3.92 & 0.732 & 3.27 & 0.955 & 5.595 & Function \\
\hline 18 & 3.84 & 0.866 & 3.33 & 0.957 & 4.100 & Function \\
\hline 19 & 3.88 & 0.868 & 3.38 & 1.092 & 3.724 & Function \\
\hline 20 & 3.94 & 0.806 & 3.35 & 0.969 & 4.882 & Function \\
\hline 21 & 3.80 & 0.880 & 3.41 & 0.928 & 3.159 & Function \\
\hline 22 & 3.94 & 0.851 & 3.36 & 0.990 & 4.641 & Function \\
\hline 23 & 3.89 & 0.853 & 3.15 & 1.095 & 5.545 & Function \\
\hline 24 & 3.84 & 0.844 & 3.28 & 0.937 & 4.575 & Function \\
\hline 25 & 3.95 & 0.950 & 3.25 & 0.920 & 5.452 & Function \\
\hline 26 & 3.87 & 0.839 & 3.37 & 1.011 & 3.953 & Function \\
\hline 27 & 3.78 & 0.854 & 3.25 & 0.930 & 4.341 & Function \\
\hline 28 & 3.89 & 0.936 & 3.12 & 0.973 & 5.983 & Function \\
\hline 29 & 3.73 & 0.892 & 3.24 & 1.031 & 3.740 & Function \\
\hline 30 & 3.87 & 0.843 & 3.28 & 0.947 & 4.777 & Function \\
\hline 31 & 4.05 & 0.795 & 3.24 & 0.915 & 6.982 & Function \\
\hline 32 & 3.75 & 0.915 & 3.15 & 0.958 & 4.718 & Function \\
\hline 33 & 3.96 & 0.863 & 3.15 & 1.006 & 6.313 & Function \\
\hline
\end{tabular}




\begin{tabular}{|l|l|l|l|l|l|l|}
\hline 34 & 3.88 & 0.740 & 3.34 & 0.877 & 4.946 & Function \\
\hline 35 & 4.06 & 0.930 & 3.33 & 0.927 & 5.788 & Function \\
\hline 36 & 3.87 & 0.769 & 3.34 & 1.051 & 4.282 & Function \\
\hline
\end{tabular}

\section{The correlation of the paragraph score with the total score of the scale}

To extract the relationship between the score of each paragraph of the scale and the total scores of the scale, the researcher used the Pearson correlation coefficient for the sample of statistical analysis of (400) forms, which are the same forms that were subjected to the paragraphs analysis in light of the two extremes, and it became clear that the values of the calculated correlation coefficients are greater than the critical value of the correlation coefficient The amount of $(0.098)$ with a degree of freedom (398) and a level of significance (0.05) to calculate the correlation of the degree of each paragraph with the total score of the scale, the researcher used the Pearson correlation coefficient where the results were as shown in Table (6)

Table (6)

The values of the coefficients of correlation of degree of strength with the overall score of the scale of problem solving skill

\begin{tabular}{|l|l|l|l|l|l|}
\hline a paragraph & $\begin{array}{l}\text { Correlation } \\
\text { coefficient }\end{array}$ & a paragraph & $\begin{array}{l}\text { Correlation } \\
\text { coefficient }\end{array}$ & a paragraph & $\begin{array}{l}\text { Correlation } \\
\text { coefficient }\end{array}$ \\
\hline 1 & 0.296 & 13 & 0.315 & 25 & 0.293 \\
\hline 2 & 0.310 & 14 & 0.315 & 26 & 0.241 \\
\hline 3 & 0.334 & 15 & 0.323 & 27 & 0.242 \\
\hline 4 & 0.356 & 16 & 0.319 & 28 & 0.229 \\
\hline 5 & 0.361 & 17 & 0.312 & 29 & 0.214 \\
\hline 6 & 0.334 & 18 & 0.204 & 30 & 0.281 \\
\hline 7 & 0.237 & 19 & 0.236 & 31 & 0.337 \\
\hline 8 & 0.165 & 20 & 0.279 & 32 & 0.263 \\
\hline 9 & 0.192 & 21 & 0.207 & 33 & 0.335 \\
\hline 10 & 0.322 & 22 & 0.233 & 34 & 0.251 \\
\hline 11 & 0.334 & 23 & 0.321 & 35 & 0.300 \\
\hline
\end{tabular}

Indicators of honesty and constancy of the problemsolving skill scale

First: Honesty

Honesty is one of the important characteristics that must be met in psychological and educational standards (Odeh, 1998: 34).
1-Virtual Honesty

Apparent truthfulness means that the scale measures what was prepared to measure outwardly (Alam, 2015: 155). This type of honesty was shown in the current scale, when paragraphs were presented to a group of experts and specialists in education, psychological counseling, psychology, measurement and evaluation 


\section{2-Construction verification}

The sincerity of the construct means the extent to which the test measures a specific behavioral feature or phenomenon (Al-Zobaie, Al-Ghanem and others, 1981: 33)

\section{Second: Stability}

It is intended that each member of the sample obtains the same scores every time the tool is applied to them, provided that no learning or training takes place in the intervals between the two applications (Al-Khatib, 2014: 130) and that the quantitative estimates in the reliability measure achieve two purposes, namely, to reveal the accuracy of the test in measuring The phenomenon and the degree of consistency and stability in performance (Al-Nuaimi, 2014: 230)

The researcher extracted the reliability coefficient for the scale in two ways

1-Retest: (Test - Retest)

To find the stability of the scale degrees, it is intended to re-apply the same scale on the same sample with a certain time difference. This method is the most clear, (Allam, 2015: 120)

The researcher applied the problem-solving skill scale to extract the consistency in this way on a sample consisting of (60) male and female mentors. Two weeks after the first application of the scale, the researcher re-applied the same scale again and on the same sample, and after identifying (Person Correlation Cofficient), the use of the Pearson Correlation Coefficient, the nature of the relationship between the first and second application degrees. The problem-solving skill is $(0.84)$.

\section{2-Cronbach's Alpha Factor}

This method is characterized by its consistency, reliability and results in calculating the correlations between all the scale paragraphs on the basis that the paragraph is a standalone measure indicating the consistency coefficient on the homogeneity between the scale paragraphs (Odeh. 1988: 3569) to calculate the consistency in this way. It was withdrawn randomly from the sample of statistical analysis and it became clear that the Fakronbach stability coefficient for problem-solving skill reached (0.82). After completing the construction of the scale (problem-solving skill) in its final form, the researcher applied the scale to the individuals of the final application sample consisting of (200) male and female mentors from the directorates The Sixth General Education Institute in Baghdad governorate (Rusafa 1, Rusafa 2, Rusafa 3, Al-Karkh 1, Al-Karkh 2, and Al-Karkh 3)

\section{Statistical indicators for search tools} A measure of problem-solving skill

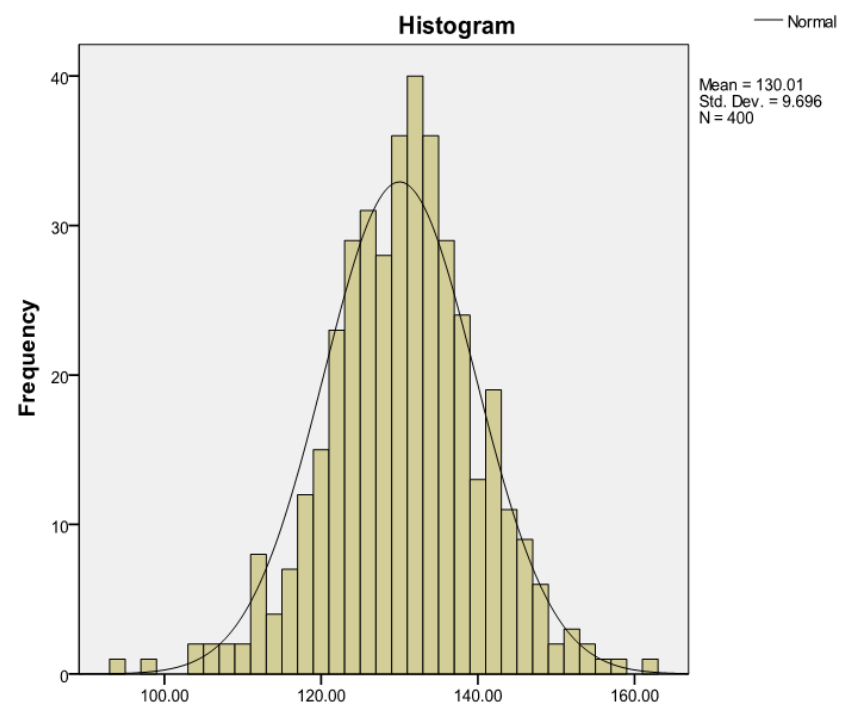


Table (7)

Table of statistical indicators for problem-solving skill scale

\begin{tabular}{|l|l|l|}
\hline $\mathrm{N}$ & Statistical indicators & Value \\
\hline 1 & Hypothesized mean & 108 \\
\hline 2 & Arithmetic mean & 130.007 \\
\hline 3 & Mediator & 130.00 \\
\hline 4 & Vein & 132.00 \\
\hline 5 & standard deviation & 9.69 \\
\hline 6 & variance & 94.00 \\
\hline 7 & skewness & -0.176 \\
\hline 8 & Kurtosis & 0.763 \\
\hline 9 & Term & 67.00 \\
\hline 10 & The lowest score & 94.00 \\
\hline 11 & Highest score & 161.00 \\
\hline
\end{tabular}

\section{THE FOURTH CHAPTER}

\section{IDENTIFY THE PROBLEM-SOLVING SKILL OF EDUCATIONAL COUNSELORS}

To identify this goal, the researcher applied the problem-solving skill scale of (36) paragraphs to the research sample of (200) male and female mentors. The results of the research indicated that the arithmetic mean of the research sample scores on the scale was $(129,825)$ degrees and a standard deviation of $(9,871)$ degrees, and upon knowing the significance of the difference between the arithmetic mean and the hypothetical average of (114) degrees, it was found that the difference was statistically significant at the level of $(0.05)$, as the calculated $\mathrm{T}$ value reached $(31,268)$, which is greater than the tabular $\mathrm{T}$ value of (1.96), with a degree of freedom (199), and this indicates that the research sample possesses the skill of solving problems, and table (8) illustrates that.

Table (8)

The result of the t-test for one sample to find out the significance of the difference between the mean of the sample scores and the hypothetical average of the scale of problem-solving skill

\begin{tabular}{|l|l|l|l|l|l|l|l|}
\hline variable & the sample & SMA & $\begin{array}{l}\text { standard } \\
\text { deviation }\end{array}$ & $\begin{array}{l}\text { Hypothesized } \\
\text { mean }\end{array}$ & \multicolumn{2}{|l|}{ T-value } & $\begin{array}{l}\text { Indication } \\
\text { level } \\
\text { Calculated }\end{array}$ \\
\hline $\begin{array}{l}\text { Problem- } \\
\text { solving } \\
\text { skill }\end{array}$ & 200 & 129,825 & 9,871 & 114 & 31,268 & 1,96 & Tabular \\
\hline
\end{tabular}




\section{Interpretation and discussion of results}

1-It is clear from the first objective that educational counselors are skilled in solving problems in a high manner according to the extracted result, and this result is natural for educational counselors and that the aspect of skill in solving problems is an important and essential aspect in the work of the educational counselor, and that the work of the counselor is based on skill in solving problems and this is what I confirmed Extension theories, especially Hepner theory

\section{Recommendations}

1-Enhancing and strengthening problem-solving skills through seminars, workshops and lectures for educational counselors held by the Directorate of Psychological Guidance and Educational Guidance in the Ministry of Education

2-Establishing programs to enhance the concept of problem-solving skills for educational counselors

3-The need to change the concept of educating educational counselors from a means of obtaining a certificate to training in innovation and problem solving in new and innovative ways, through which the counselor learns about problems and helps him to process information, make decisions, generate alternatives, evaluate and form a knowledge structure in one way or another to the solution

4-The need to develop mental capabilities, manage relationships, and foresight among educational counselors

\section{The proposals}

To complement the aspects of the current research, the researcher suggests the following:

1-Conducting a similar study in all Iraqi provinces for educational counselors

2-Preparing a training program based on modern indicative methods to develop the skill of solving problems for educational counselors

3-Study the research variable, problem-solving skill and its relationship to some of the following psychological variables: (positive self-concept, successful personality).

\section{REFERENCES}

Abu Jadu, Salih (2008): Practical Applications in the Development of Creative Thinking Using The Theory of Innovative Problem Solving. Jordan, Amman: Practical Jaffa House for Publishing and Distribution

Al-Bahdal, Dakhil Bin Muhammad, (2014): The problem-solving skill of the psychological counselor and its relationship to his instructive performance, Journal of Educational Sciences, Volume 26, Issue (1), pp: 221-252, Riyadh

Jaber, Jaber Abdel-Hamid (1999): The Psychology of Learning and Theories of Education, Ninth Edition, Arab Renaissance House, Cairo

Hamdi, Muhammad Nazih and Khatabiah, Mubarak (2013): The effect of field training on improving perceived self-efficacy and counseling skills among students of psychological counseling for the Yarmouk and Jordan universities, Journal of the Association of Arab Universities for Research in Higher Education. Volume (33) Issue (4) pp: 213-234

Dreib, Muhammad Jabr (2014): Lateral thinking and problem-solving skills of distinguished and ordinary school students. Journal of Kufa Studies Center, Field and Applied Studies. University of Kufa College of Education for Girls, p. 381

Abbas, Muhammad Khalil Muhammad, Bakr Nofal (2009): Introduction to the Curriculum of Educational Research in Education and Psychology, Dar Al-Masirah for Printing and Publishing, Amman, Jordan

Allam, Salah Al-Din Mahmoud (2015): Psychometrics, 1st Edition, Dar Al-Fikr for Publishing and Communication, Amman, Jordan

Odeh, Ahmad Suleiman (1988): Measurement and Evaluation in the Teaching Process, Second Edition, Dar Al-Amal for Publishing and Distribution, Jordan 
Taher, Dalal Kazem Ibrahim, (2006): - Training needs for educational counselors from the point of view of educators, College of Education, Al-Mustansiriya University (unpublished master's thesis)

Qatami, Nayfeh. And Al-Zwain, Fartaj (2009): integrating the kurt into the school curriculum. Jordan Amman: Debono Publishing and Distribution

Al-Khatib, Salih Ahmad (2014): Psychological counseling in the school, its foundations, theories and applications, 1st Edition, University Book House, Emirates

Al-Zobaie, Abdul-Jalil and Al-Ghannam, Muhammad Ahmad (1981): Curricula for Education and Psychology, 1st Edition, Baghdad University Press

Al-Adl, Adel, and Abdel-Wahhab, Salah (2003): The ability to solve problems and metacognitive skills of the ordinary and the mentally superior. Journal of Psychological Studies, Journal of the College of Education, Ain Shams University

Al-Kubaisi, Waheeb Majeed and Al-Dahri, Saleh Ahmad (2002): Introduction to Educational Psychology, Babylon, University of Babylon for Publication and Distribution

Al-Naimi, Muhannad (2014): Psychometrics in Education and Psychology, 1st Edition, Central Press, University of Baghdad Mohsen, Abdul Rahim Saleh, (1993): Communication skills for the educational counselor in middle schools in Baghdad, AlMustansiriya University, College of Education (unpublished master's thesis).

Mustafa, Talal Abd al-Muti (2011): The Skills Requirements for Social Counselors in the Basic Learning Stage, Damascus University Journal, Volume 27, Issue $1+2$.

Melhem, Sami Muhammad (2000): Measurement and Evaluation in Education and Psychology, Dar Al Masirah for Publishing and Distribution, Amman, Jordan.

Phenomena of Burn Patients, Specialized Psychological Culture Journal, Volume (8), Issue (29), P .: 102.

Nazih, Hamdi (1998): The relationship of problem-solving skills to depression among students of the University of Jordan, Journal of Psychological Studies, Issue (25).

The Ministry of Education (2002). A guide for educational guidance, prepared by a specialized committee, General Directorate of Secondary Education: Directorate of Educational Guidance.

Harris, K . \& Hal pin, G. (1985),p. 136- 140.

Heppner, P . P,G.W .Neal ,\& L.M. Larson ( 1984 ) : Problem solving training as prevention with college students,

Horrocks, John E. \& Weinberg ,Selman A. (1970) p. 51.

John , B (2010). Perceived roles and Perception experiences of elementary School Guidance and Counseling, (27), 216- 226

Lefrancois ,(20oo):Theories of human learning, WalSowth , $U^{\wedge}$ the $d$

Klousmeier, Herbert J.and William Goodwin.(1971)p.123.

Zimmeman ,B .\& pons, M . (1990).Student differences in Self regulated learning :Relating grade, Sex and giftedness to self -efficacy and steategy use. Journal of Educational Psychology, 82 (1) , 52-58. 